\title{
Getting Out: A Struggle for Autonomy in Physical and Social Confinement*
}

\author{
Yasemin Güniz Sertel \\ Istanbul University, Istanbul, Turkey
}

\begin{abstract}
This study comprises an analysis of the American feminist playwright Marsha Norman's play Getting Out from a socialist-feminist perspective. Getting Out is about the physical and psychological confinement of the victimized protagonist Arlie Holsclaw in contemporary patriarchal American society. Throughout the play, the factors that victimize Arlie are given as the outcomes of a patriarchal society with its basic institutions as the family, educational system, religion and the law symbolized by the correctional rehabilitation. These factors which are under the hegemony of patriarchal authority shape Arlie's life as beginning from her childhood in the past and define her present search for female autonomy.
\end{abstract}

Keywords: female autonomy, confinement, rehabilitation, patriarchal society, female victimization

\section{Introduction}

Female autonomy can be defined as a woman's self-determination in the acceptance or rejection of the norms, models or standards defined and determined by the dominant ideologies in a society according to her own desires and needs. And this self-determination proves itself in women's ability to create new norms and structures for themselves instead of the patriarchal standards in order to be the "owner" of their own lives. The endeavors of many woman playwrights who try to give voice to women's unheard voices and to depict the growing female consciousness in their plays can be seen as a part of woman's struggles to own their autonomies. As Norman suggests,

...The appearance of significant women dramatists in significant numbers is a real reflection of a change in women's attitudes toward themselves. It is a sudden understanding that they can be, and indeed are, the central characters in their own lives... (Norman, as cited in Burke, 1996, pp. 203-204)

Despite the attempts of women towards liberation, female autonomy in patriarchal societies is restricted and inhibited by male power and patriarchal authority which are manifested in various traditions and institutions of the society. Whether consciously or unconsciously, women are shaped by the regulatory norms of the patriarchy in their way of behavior. Even their way of thinking is determined by the norms and institutions of the society, which are basically under the hegemony of patriarchal authority. The predicament of Norman's female characters is also a reflection of the average woman in American society, even today.

\footnotetext{
* This paper is based on the discussions of the Ph.D. dissertation "The Female Autonomy: Women in Marsha Norman's Plays" Istanbul 2004.

Yasemin Güniz Sertel, Ph.D., Assistant Professor, Faculty of Letters, The Department of American Culture and Literature, Istanbul University.
} 
Getting Out deals with the physical and psychological imprisonment of an ex-criminal in contemporary patriarchal American society after she is released from the prison in which she was rehabilitated. The play also discusses the universal theme of female subordination in the basic institutions of the patriarchal societies while the main character of the play is in search of a survival in freedom.

In Getting Out, Marsha Norman exemplifies the struggle for female autonomy on two levels; as a woman playwright writing in the male territory and as a woman trying to define her existence in a patriarchal society as depicted in the struggles of the main character in the play.

The audience/reader is informed that the main character Arlie Holsclaw has experienced a life of suffering and victimization throughout her life. In addition to having spent a childhood of poverty, she was also sexually abused by her father. Her mother instead of protecting Arlie, prefers to deal with her own abuse by her husband. Thus, Arlie has become a prostitute and then she is put into prison due to prostitution and a series of crimes. During her imprisonment, she is accompanied by a priest who convinces her that "a bad self" exists in her from which her soul must be saved. One of the most dramatic scenes of the play takes place when Arlie commits suicide by stabbing herself with a fork thinking that she has saved her soul. However, she is saved and she is given rehabilitation in order to be transformed into an acceptable and a productive member of the society. As a result of this process, she has become "a completely rehabilitated subject" (1: 5) ${ }^{1}$, called Arlene in her new identity and considered as a free woman.

\section{Tactics of Woman Playwrights as an Alternative to Male-Writing}

In Getting Out, Arlene's life is surrounded and shaped by meta-prisons and, her survival in the presents is conditioned by a past that she can not escape from. Although the action of the play takes the reader/audience to the first day of Arlene's free life, there are various "flashbacks depicting Arlie's passage from sexually abused child to juvenile delinquent to unwed mother, prostitute, and convict" (Scharine, 1989, p. 186). Therefore, in parallelism with Arlene's journeys between the past and the present throughout the play, Norman makes use of a technique called the "spiralling plot pattern" in the construction of the narrative structure of the play, which is explained by Janet Brown as follows:

Female writers tend to employ narrative structures characterized by circular or spiralling patterns, involving a communal protagonist... but resisting the traditional resolution or indeed, any clear-cut resolution. Although essentially chronological, the narrative often includes periodic returns to the past resulting in a spiralling progression. (Brown, 1991, pp. 14-15)

This technique of the "spiralling plot pattern" is actually opposed to the chronological and linear movement of the traditional patriarchal narrative structure. Thus, it can be considered as an alternative to the conventional male-writing. In Getting Out, although Arlene's story is articulated by a conventional chronological narration, the flashbacks constantly take the reader/audience to her past and therefore, the past and the present are juxtaposed.

The setting of the play is a dingy one-room apartment in the outskirts of Kentucky which as a domestic interior setting reminds the reader/audience of the confinement and entrapment Arlene/Arlie has experienced in the actual prison. The bars on the windows are also evocative of a real prison cell. As the stage directions

\footnotetext{
${ }^{1}$ Norman, M. (1998), Getting Out, included in Marsha Norman: Collected Works-Contemporary Playwright Series (1-58). Lyme: A Smith and Kraus Book. The Play was first performed at Actors Theatre Louisville, Louisville-Kentucky, in 1977. (All the quotations from the play in this paper are taken from this edition).
} 
explain, "A catwalk stretches above the apartment and a prison cell... connects to it by stairways. The apartment must seem imprisoned" (1: 5). Although Arlene insistently wants to get rid of the bars on the window by pulling them out, the landlord, with all his authority rejects to remove them since they are used "to keep the burglars out" (1: 9). Yet, instead of keeping the burglars out, these bars are symbolically there to keep Arlene in the confinement of patriarchal authority.

\section{The Significance of the Title}

Besides the setting, the title of Getting Out also has significance since it bears various symbolic meanings and it refers to a variety of limitations presented in the play. First of all, Getting Out indicates Arlene's getting out of prison as a completely rehabilitated subject after staying there for eight years. Secondly, Getting Out is Arlene's hopeless endeavors to get out of the "life outside", because although she is liberated from the actual bars of the prison cells, the life awaiting her outside is not much different from that in the prison. The play takes place in a prison within a prison since the prison mentioned in the play as "Pine Ridge Correctional Institute" is only a small cell of the bigger prison, that is, the society with all its oppressive institutions. It is in this larger prison that Arlene will be suffocated and victimized due to the inhibitions and limitations of the dominant patriarchal institutions. And it is this social world that violates and oppresses Arlene through its moral institutions which are religion, education, correctional rehabilitation and the family. On the third level, Getting Out is Arlie's wish to get out of Arlene. Arlie's way of thinking, her feelings, her freedom and even her life are repressed by the identity of Arlene, which is shaped by the institutions of society. As a result, Arlene becomes a typical product of those institutions which do not permit Arlie to live freely and even try to kill her. On the other hand, the opposite of this perspective can be suggested, that Getting Out is Arlene's desire to get out of Arlie, the "hateful" and "bad self" who connects Arlene to her past life and past memories she wants to forget. Her attempted suicide during her rehabilitation in the prison is the way Arlene tries to get out of Arlie:

Arlene: ... then that night it happened, ....an I'm standing there tellin' 'em, but there is all this blood all over my shirt an I got this fork I'm holdin' real tight in my hand... and there's all these holes all over me where I been stabbin' myself and I'm sayin' Arlie is dead for what she done to me, Arlie is dead an it's God's will... (2: 54)

\section{Arlie and Arlene: Illustration of the Split Protagonist}

In Getting Out, the Arlie/Arlene dichotomy constitutes one of the most significant aspects of the play. Throughout the play, the central female role is represented by two characters, one playing Arlene who has recently been released from prison and is settling into an apartment; the other playing Arlie, Arlene's past self, imprisoned upstage during much of the action. Indeed, Arlie is the younger and unreformed self of Arlene and she constantly accompanies her. Norman explains this protagonist character of the play in the stage directions as follows:

Arlie is the violent kid Arlene was until her last stretch in the prison... There must be hints of both physical type and gesture that Arlie and Arlene are the same person, though seen at different times in her life. (Norman, 1998, p. 3)

Bringing onstage both Arlene, "a thin, drawn woman in her late twenties" (Norman, 1998, p. 3) and Arlie, the violent younger self who was imprisoned eight years ago is the way Norman makes use of the technique called "split protagonist". This technique is one of the forms preferred by female writers to exemplify the difference of female consciousness and way of thinking, especially in contrast to the dominant male perspective. 
Although Arlie and Arlene constitute the same identity, each character represents a different phase of the protagonists' life. To elaborate, Arlie represents Arlene's past life; she embodies Arlene's memories, her past feelings, desires, life style and experiences. Norman herself explains this function of Arlie in the stage directions as follows:

Arlie, in a sense, is Arlene's memory of herself, called up by fears, needs and even simple word cues. The memory haunts, attacks, and warns. But mainly, the memory will not go away. (Norman, 1998, p. 3)

Throughout the play, Arlie's imagined presence in the words of Lynda Hart is what Norman uses as a "liberating strategy" for Arlene from patriarchal inhibition and confinement as a tactic of women playwrights (Hart, 1989, p. 8). Therefore, flashbacks that occur throughout the play can be seen as Arlene's retreat from and even her escape from the patriarchal confinement. Although she also remembers the pains she suffered in the past, Arlene is released from the boundaries and limitations established around her only in her memories, and retreating into Arlie is one of the few ways of finding peace for her.

Arlie becomes Arlene after spending time in "Pine Ridge Correctional Institute for Women" (Norman, 1998, p. 3), where she is first rehabilitated and then socialized. While she was free, violent and rebellious in the identity of Arlie, what she experiences in the institute transforms her into a meek, quite and rehabilitated woman. As a matter of fact, she is first presented to the audience by the warden as a successful product of the "complete rehabilitation" process, a model output of institutional reform who has also been successfully integrated into community life, and an ideal example for the other prisoners. Institutional norms define certain ways of behavior as acceptable, and as Arlie's attitudes do not fit into these definitions, they regard Arlie as a dangerous threat that must be exterminated. Therefore, they present Arlie's rehabilitation to the audience as a sign of social progress, whereas, in fact, it is these restrictions and definitions which cause the emergence of two different identities, the two selves of the same character. Thus while Arlene represents conformity to social institutions as a result of her rehabilitation, Arlie represents a rebellion against those institutions. Throughout the play, Arlene's "rehabilitation" is manifest in her manner of speech, since her tone is obedient throughout the play. In fact, through her speech, Arlene is perceived not only as a different person than Arlie, but as a selfless person. Arlie who questions her new position with the words "No, I don't have to shut up" (2: 42) has been silenced in the identity of the rehabilitated Arlene. Arlie's suicide attempt in prison is a symbolic representation of her silencing through the rehabilitation process. Her attempted suicide is actually a rejection of her real self. By rejecting her real self, Arlene has obeyed and conformed to the norms, values and way of living of the patriarchal society. As a result, she is perfectly socialized, and thus turned from a criminal into a victim. It is after this incident that Arlene rejects to be called Arlie by telling: "Arlie girl landed herself in prison. Arlene is out, okay?" (1: 7). However, this transformation is nothing more than a "self-destructive feminization" in the words of Spencer (Hart, 1989, p. 154).

\section{The Protagonist as a Victim of the System}

As a matter of fact, Getting Out can be considered as a political play. In analyzing Getting Out as a political play, the factors that turn Arlene into a victim must be perceived as the result of the flaws of the social system with all its basic institutions such as the family, education, religion and the law symbolized by the correctional rehabilitation. These factors which are under the hegemony of the patriarchal authority condition Arlie's life and define its directions as beginning from her childhood in the past. 
Arlene's family life and her familial relationships constitute the most significant aspect of her past. The significance of her family life is symbolized by one of Arlene's memories at the end of the play in which Arlie is locked up in a closet by her sister. The play ends with Arlie and Arlene laughing together at this memory. This memory of being locked into a closet which belonged to her mother indicates that Arlie is imprisoned in the memories and values of her family, and though not positively, her family will always be with her. Her aggressive behavior, rebellious streak and criminal tendencies are the results of the abuse she suffered during her childhood. As a small child, Arlie is raped by her father who later paid her to be silent. Arlie's rape is the beginning of the male oppression on her, which starts at an early age, and will indeed be followed by a series of different versions throughout her life. This rape also represents the sexual exploitation of women by men and women's subjugation in return, which may appear in many forms. Arlie's case can be seen as a kind of female sexual slavery which begins at home and extends over every phase of her life. As Barry suggests,

Female sexual slavery, in all its forms, is the mechanism for controlling women through the sexist power ethic, either directly through enslavement as a threat that is held over all other women. This is the generalized condition of sex colonization. (Barry, 1984, pp. 413-414)

As understood from Barry's remarks, the male gender is perceived to be the first and the foremost basis of power and authority in society. "It is in this private sexual relationship between man and woman that fundamental inequality is established" and it is under these circumstances that women are perceived as beings whose responsibility is to provide sexual services to men (Barry, 1984, p. 413). Thus, this condition provides the sources of the gender-specific sexual slavery. Arlie's case is an example to incest which is experienced in the family and directed to the daughter as a form of female sexual slavery. However, Arlie's sexual exploitation cannot be perceived merely as the sexual abuse of a child, but a form of prostitution, since the father pays Arlie in return for her sexual services. This situation is implied through a conversation Arlie has with the School Principal in one of her memories:

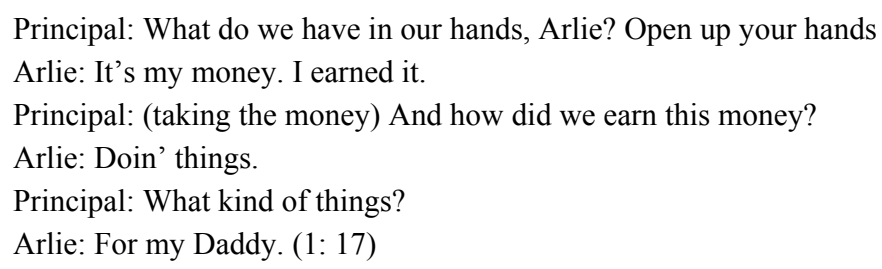

Her father's incestuous relationship with Arlie results in other sexual relationships that she experiences with different men. As Scharine suggests "one of the tragedies of incest is the likelihood that its female victim will pass from the home to still other coercive sexual relationships" (Scharine, 1989, p. 193), therefore, all men who enter her life try to exploit Arlie in different ways. Arlie's relationship with Carl who is introduced in the stage directions as "Arlene's former pimp and partner in various crimes, in his late twenties" (Norman, 1998, p. 3) reflects her abusive relationship with her father since while the father bears the role of protector in the family, Carl as her pimp bears the same role when Arlie is older. Arlie's experience with female sexual slavery in her relationship with Carl is twofold: Carl uses Arlie's body for his own sexual satisfaction as well as for that of others. Thus Arlie's body becomes not only an agent of sexual satisfaction for Carl, but it also becomes a commodity to be bought and sold for financial gain. 
Throughout the play, besides sexist oppression of women, the main character is also victimized in other ways, one of which is the oppression of a powerless woman by a powerful woman. In Getting Out, one of Arlie's most powerful female oppressors is her own mother, who is partly responsible for her predicament. In general, oppression of women by other women derives from the differences between them such as economic, social, class and racial distinctions. As a matter of fact, in each case the female oppressor's attitude can be regarded as her "desire for integration and participation within a larger social and public community as a means of overcoming a condition of marginalization and powerlessness" (Felski, 1989, p. 150). The female oppressor digests and then imitates the norms and tactics of the larger system in order to be accepted by it and have a safe place in it. In Getting Out, Arlie's mother becomes a part of this structure by keeping silent and protecting her husband by telling "He weren't a mean man, though, your daddy" (1: 14).

Another female oppressor of Arlie is the School Principal, who is introduced in the stage directions only as a "female" (Norman, 1998, p. 3). Besides being a woman oppressor, the School Principal is also the symbol of Arlie's oppression by the education system. The system, instead of teaching or educating a child who has criminal tendencies, chooses to discipline her by punishing her and suggesting to her that she is not normal. As she suggests: "You're going to get out of regular school to be disciplined in a special school. You've earned it. Well, they'll know exactly what to do with you" (1:17-18).

Throughout Getting Out, the loudspeaker voice of the prison in which "a woman's voice is preferred" (Norman, 1998, p. 4) according to the stage directions is another example of female oppressors. The loudspeaker voice by directing, commanding and disciplining the prisoners stands for the institutional authority. Besides being a tool of the patriarchal system, this voice depicts how Arlene is stripped off her individualistic qualities in order to be reduced to a subject position through rehabilitation within the prison. As a matter of fact, Foucault defines the function of prison as an "omnidisciplinary system" as well as "an exhaustive disciplinary apparatus" which "assumes responsibility for all aspects of the individual, his physical training, his aptitude to work, his everyday conduct, his moral attitude and his state of mind" (Foucault, 1982, pp. 235-236). Therefore, within the prison, rehabilitation as "a principle of correction" in the words of Foucault becomes "the most powerful machinery for imposing a new form on the perverted individual" (Foucault, 1982, p. 236). In order to render the rehabilitation more effective and to guarantee their submission, the isolation of the convict is also accepted as a significant element. As for Foucault, "the isolation of the convict from the external world, from everything that motivated the offence [becomes a mechanism] of power that will not be overthrown by any other influence" (Foucault, 1982, pp. 235-236). Therefore, "solitude is the primary condition of total submission [and] it provides an intimate exchange between the convict and the power that is exercised over him" (Foucault, 1982, pp. 236-237). In Getting Out, Arlie also experiences isolation since she is put into a segregation cell in order to change her mentality and transform her perverted individuality into a personality that is approved by the institutional norms. When Arlie in her segregation cell tells "I been in this ad-justment room four months... When am I gittin' outta here?", the answer of the Warden proves Foucault's argument:

Warden: That's up to you... If we felt the way you seem to think we do, everyone would be in lockup. And if you ever do it again, or anything like it again, you'll be right back in lockup where you will stay until you forget how to do it. (2: 36- 38- 39)

Another corrective method applied on the criminals in prison is the supervision and assistance offered to them and accepted as "the principle of auxiliary institutions" in Foucault's words which can be defined as 
"measures of supervision and assistance until the rehabilitation of the former prisoner is complete" (Foucault, 1982, p. 270). During her imprisonment, Arlie, too, is offered support by a prison chaplain while she is in her segregation cell. Although this religious support represented in the identity of a prison chaplain results in Arlie's transformation into Arlene and ends her rehabilitation, it also causes her victimization since this chaplain diverts her towards committing a suicide by motivating Arlie to kill her "hateful self":

Arlene: This chaplain said... Arlie was my hateful self and she was hurtin' me and God would find some way to take her away... Arlie must be dead for what she done to me, Arlie is dead and it was God's will so I could be the meek ... the meek, them that's quite and good an git whatever they want. (2: 54)

By deciding to commit suicide through the encouragement of the chaplain, Arlie terminates her real personality. On the other hand, Arlie's stabbing herself with a fork which is also a phallic symbol also symbolizes the mutilation of the system by Arlie herself. Even the suicide tool represents the power of male authority, which has a significant role in killing the real self of Arlie. Meanwhile, the chaplain by calling her Arlene and by offering a different self for her, destroys Arlie's real identity and actualizes her initiation into a new personality, which is the aim of rehabilitation. In her new identity, Arlene being a model of institutional reform is presented to the audience as an example of social progress. As a result of her training, her body and mind have been corrected to enter the workplace as a marketable member of the society thus, to function as contributive elements in the forces of production. However, Arlene's training places her in a worse situation of oppression, as well as revealing the dilemma of the system since as she mentions "Ex-cons can't get no license" (1: 19) to work at a public sphere. Therefore, even after her rehabilitation and training, Arlene is not offered much job opportunity at the "outside", which reflects the indifference of the system towards even the very figures of institutional reform it creates. Although after getting out of prison Arlene tries to establish a life for herself, the rehabilitation applied on her assigns her permanently to a passive position. What she has learned after her rehabilitation is that "the meek, quite, good" (2:54) are the ones that survive. In fact, Arlene is what institutions have shaped her into, so her life is a tool in their hands to divert to any direction they want. However, these institutions offer very limited possibilities to Arlene and as a result, even after her release, her life is imprisoned in those very limited directions. Towards the end of the play, Arlene outcries her unending imprisonment in this outcry:

Arlene: What am I gonna do? I can't get no work that will pay good It'll be years fore I have a nice rug for this place. I'll never have some ol' Ford to drive around... and I'll have to wear this fuckin' dress for the rest of my life. What kind of life is that? $(2: 53)$

\section{Conclusion}

In the story of Arlie/Arlene, there is the picture of a woman oppressed and victimized by her past, her family, and the society with its various patriarchal institutions. As long as she continues to be governed by the institutions of the same system she cannot experience a real liberation even though she has acquired a new acceptable identity, which also means that she cannot act as a complete autonomous woman.

\section{References}

Barry, K. (1984). Female sexual slavery. In A. M. Jaggar and P. S. Rothenberg (Eds.), Feminist frameworks-Alternative theoretical accounts of the relations between women and men (2nd ed., pp. 405-415). New York, London, Toronto: McGraw-Hill Publishing Company. 
Burke, S. (1996). American feminist playwrights: A critical history. New York: Twayne Publishers.

Brown, J. (1991). Taking center stage -Feminism in contemporary U. S. drama. London: The Scarecrow Press.

Felski, R. (1989). Beyond feminist aesthetics: Feminist literature and social change. Massachussets: Harvard University Press.

Foucault, M. (1982). Discipline and punish-The birth of the prison. Middlesex: Penguin Books.

Hart, L. (1989). Introduction: Performing feminism. In L. Hart (Ed.), Making a spectacle: Feminist essays on contemporary women's theatre (pp. 1-21). Ann Arbor: The University of Michigan Press.

Norman, M. (1998). Getting Out, included in Marsha Norman: Collected Works_Contemporary Playwright Series (1-58). Lyme: A Smith and Kraus Book. The Play was first performed at Actors Theatre Louisville, Louisville-Kentucky, in 1977.

Scharine, R. G. (1989). Caste Iron Bars: Marsha Norman's Getting Out as political theatre. In J. Redmond (Ed.), Themes in drama: Women in theatre (pp. 185-198). Cambridge: Cambridge University Press.

Sertel, Y. G. (2004). The problem of female autonomy: Women in Marsha Norman's plays (Ph.D. dissertation, İstanbul Üniversitesi, Sosyal Bilimler Enstitüsü). 